\title{
BIBLIOGRAPHY OF LITERATURE ON WOMEN IN AGRICULTURE AT THE RUTGERS UNIVERSITY LIBRARIES
}

\author{
BY LILL MAMAN \\ Ms. Maman is Reference Librarian at Mabel Smith Douglass Library, \\ Rutgers University
}

The Rutgers University Libraries' largest collection on women in agriculture is located at the Mabel Smith Douglass Library. Douglass Library serves students and faculty at Douglass College, the largest women's college in the United States, and Cook College, the Land Grant College of New Jersey, and the Mason Gross School of the Arts. The collection on women in agriculture includes profiles on farm women, anthropological studies and case studies, particularly from the Third World. Most of this literature is written by women. When Ester Boserup, an economist, published her book, Women in Economic Development in 1970, she was one of the first to focus on the relationship between women's role and economic development. Boserup documented the connections between certain land use patterns and agricultural techniques and its relationship to division of labor based upon gender. Experts on both colonial and contemporary agriculture have viewed crop production as being a male oriented task because that reflected the traditional European concepts. Consequently, women in underdeveloped countries were rarely involved in the development process. They were not permitted to participate in training programs for agricultural modernization and development and their contributions to agriculture have been ignored. Rural women were deprived of their right to land ownership as a result of land reforms instituted by male oriented European administrators. Boserup's study initiated a considerable amount of debate and research on the participation of women in world agriculture. The books cited in the bibliography reflect women's roles and contributions to agriculture in the industrialized countries and the developing countries. These books have been acquired for the Douglass collection to serve the disciplines of agriculture, rural sociology and women's studies. A growing role for women in agriculture is anticipated in the future as the struggle for women's rights grows and receives more serious consideration in the world arena. 
Books on women in agriculture in the Rutgers University Libraries are representative of the existing works on this topic. This annotated bibliography is broadly arranged by four regions: The Americas, Africa, Asia and Australia, and Europe to illustrate the global perspective and diversity of cultural patterns involving women in agriculture and to assist readers in selecting specific books for their interest. It is my hope that this fascinating topic will excite you and whet your appetite for additional reading.

\section{The Americas}

Allen, Ruth Alice. The Labor of Women in the Production of Cotton. New York: Arno Press, 1975.

This monograph deals with the life and work of women who lived on the cotton farms of Texas and who formed a considerable part of the group classified in the census of 1920 as "farm population". The female portion of this farm population consisted of 1,092,000 individuals, but this study considers only the females 14 years or older. Many statistical tables are provided on such topics as amount of field work done by Negro women, household work, periodical literature, books borrowed from libraries, average number of children under 15 , marital status, etc. The questionnaires used in making this study are also reproduced, and we find some references for further reading and a detailed index in the back of the book.

Douglass, Alexander HD6073.C662U52 1975

Atkeson, Mary Meek. The Woman on The Farm. New York: Century, 1924.

In preparing for writing this book the author met and interviewed many hundreds of farm women at field days and organization meetings in many parts of the country. Nearly a thousand pieces of correspondence were received from every state of the Union, and the author had access to thousands letters from farm women, received in 1920 by Farm and Home and in 1922 in The Farmer's Wife. The author concludes that women on the farm are optimistic and do not contemplate quitting their work. In the Appendix is a list of additional readings for farm women. Douglass HT421.A873W 
Bartley, Paula and Cathy Loxton. Plains Women: Women in the American West. Cambridge, MA: Cambridge University Press, 1991.

This small book from the WOMEN IN HISTORY Series examines the sociological and physical challenges faced by women who settled in the Midwest. Bartley and Loxton describe the contrast between Whites and Native Americans on the Plains and particularly the vital roles of Native American women in that environment.

Douglass F596.B274 1991

Binnie-Clark, Georgina. Wheat and Woman.Toronto: University of Toronto Press, 1979.

This autobiography was first published in 1914 and tells the story of an English woman writer settling as a wheat farmer on the Canadian prairie in Saskatchewan. She came from England to visit her brother who had started farming, but did not succeed. She decided to remain on the prairie in spite of the poverty and diversity and became a prosperous farmer. The life of a woman farmer is quite different from the life of a farmer's wife on the prairie. She describes her experiences during the first three years and offers advice to other women who would like to make their living in agriculture.

Douglass S417.B5A35 1979

Bourque, Susan C. and Kay Barbara Warren. Women of the Andes: Patriarchy and Social Change in Two Peruvian Towns. Ann Arbor, MI: The University of Michigan Press, 1981.

This book is about women in the agricultural community of Mayobamba, a settlement of 450 people, and Chiuchin, a trade center with 250 residents on the mountainside north of Lima, Peru. The first part of the book examines women's position in the communities and particularly women's subordination, marriage and family politics. The second part of the book discusses the sexual division of labor and how women participate in a broad range of agricultural activities, and the rigidly enforced cultural patterns governing access and sex role stereotypes. The book also describes women's position in the agrarian class system, women's consciousness and participation in the patriarchal power structure and the effect of social change and national development on the women in the two communities. There is a bibliography and an index in the back.

Douglass, Alexander, Dana, Kilmer HQ1572.B68 1981 
Centro de Investigacion y Estudios de la Reforma Agraria (Nicaragua). Tough Row to Hoe: Women in Nicaragua's Agricultural Cooperatives. Rural Women's Research Team, Center for the Study of Agrarian Reform (CIERA), Managua, San Francisco, CA: Food First, Institute for Food and Development Policy, 1985.

The Sandinista revolution in Nicaragua initiated an agrarian reform law in 1981; this was the first time in Latin America that women were explicitly included as beneficiaries of reforms in the agricultural sector. The objective of this study is to analyze the process through which women became members of the cooperatives, to determine the extent which women's participation is a result of the agrarian reform law, what factors encouraged women to participate in the cooperatives, and what were the barriers they encountered.

One of the more important findings of this short study revealed that as long as women carry the full burden of child care and housekeeping, they cannot participate in agriculture on an equal basis with men. The study illustrates the difficulties of integrating women into the cooperatives. One year after the agrarian reform, only $6 \%$ of the cooperative members were women. However, the female members were able to enhance their technical, organizational and political development. Douglass HD6073.A292N5613 1985

Deere, Carmen Diana and Magdalena Leon de Leal. Women in Andean Agriculture: Peasant Production and Rural Wage Employment in Columbia and Peru. Geneva: International Labour Office, 1982.

The census data of the Andean region suggest that the participation of rural women in agriculture has decreased in recent decades, but the authors of this monograph imply that it may in fact have increased.

The study draws on peasant household sample surveys for three areas of Columbia and Peru. The census data indicated that in peasant smallholder agriculture, women participate in both field work and decision-making. The book contains over 30 statistical tables.

Alexander HD6073.A292N5613 1985

Fairbanks, Carol. Prairie Women: Images in American and Canadian Fiction. Yale University Press, 1986.

This is a study which looks to the past at the lives of prairie women in the United States and Canada, "seeing with new eyes, and entering old texts from a feminist critical perspective". The author analyzes the 
way women writers have described the experiences of pioneer prairie women and how they described the "new" land-the land that was new to the pioneers but old and familiar to the native people. The book is illustrated and has a bibliography and index.

Douglass, Alexander, Dana PS273.F34 1986

Fairbanks, Carol and Sara Brooks Sundberg. Farm Women on the Prairie Frontier: A Sourcebook for Canada and the United States. Metuchen, NJ: Scarecrow Press, 1983.

This sourcebook is intended for students, teachers and general readers who wish to explore the historical and literary materials of the grasslands of Canada and the United States. We find four essays introducing readers to the land and the people, the history and the fiction. The second part is an annotated bibliography on history, fiction, nonfiction, and women's fiction.

Douglass Ref., Alexander HQ1438.A17F34 1983

Fairbanks, Carol and Bergine Haakenson. Writings of Farm Women 1840 1940: An Anthology. New York: Garland Publishing, 1990.

A collection of stories by farm women relating their experiences with various farming techniques, flower gardens, animals, religious life, politics, and destruction of crops by grasshoppers and drought.

The women do not boast about their ability to endure, they describe the experiences as they occurred. The more painful situations are often passed over quickly and "dignity is the dominant tone struck by women who worked hard and developed self-confidence", say the editors in the preface. The book has a short index.

Douglass HQ1410.F17 1990

Fink, Deborah. Agrarian Women: Wives and Mothers in Rural Nebraska 1880-1940. Chapel Hill: The University of North Carolina Press, 1992.

Fink is an anthropologist who returns to Boone County in her home state of Nebraska to gather data on what it was like to be a woman in rural Nebraska in the late 19 th and early 20 th century. She discovered that it was not easy to get the women to talk about the past, because it contained experiences that were heartbreaking and humiliating. The topics covered are land ethics, women's work, fertility, rural violence, agrarianism and current farm politics. In the final chapter the author offers a history of agrarianism and rural development in Boone County. 
The appendix discusses the sample of the women who were interviewed. The book includes a bibliography and index.

Douglass HQ1438.N2 1992

Fink, Deborah. Open Country, Iowa: Rural Women, Tradition and Change. Albany: State University of New York Press, 1986.

This is an anthropological study of a rural community in Iowa in the years following World War II. The data was derived from in-depth interviews with 43 women and 5 men, and census statistics and historical records from churches and the county extension office.

In the chapter "Eggs: A Case in Point" the author discusses the changes that took place in women's control of the egg production. This had been women's work and it provided supplementary income to the farm families during the years 1925 to about 1974. However, technological changes in poultry and egg production forced the small-scale women producers out of business. The loss of income forced women to take low paying jobs in the nearby towns, thus changing the nature of farming in rural Iowa. The book includes a bibliography and index.

Douglass, Alexander HQ1438.I7F56 1986

Jensen, Joan M. Loosing the Bonds: Mid-Atlantic Farm Women, 1750-1850. New Haven: Yale University Press, 1986.

This well documented account of farm women's work and lives is set in the Philadelphia area during the years 1750 to 1850 . It tells of women who remained on the farms at a time of increasing industrialization. Using wills, inventories, poorhouse and church records, Jensen explains women's efforts to contribute to farming, to household work and to the community. The book focuses on the commercial sphere where women directly shared in economic development. In the chapter on "Butter Trade" the author portrays the women as shapers of the emerging commercialization of the farms. The butter making became a cottage industry that provided an important source of income to farm families during a period of economic transition.

The last part of the book includes studies of women's activities in religion, education and reform. In the Appendix are tables on household inventories from Chester and Castle Counties in Pennsylvania, and statistics on butter prices in Philadelphia from the years 1784 to 1849. There are also notes on the sources used and an index. Douglass, Alexander, Camden, Kilmer HQ1438.A12J46 1986 
Jensen, Joan M., Editor. With These Hands: Women Working on the Land. Old Westbury, NY: The Feminist Press, 1981.

The editor of this anthology explains in the introduction how difficult it was to find documents on women working on the land. Most rural women left no records of their lives because they were not literate. Native American women had no written language of their own, and African-Americans in the south were seldom permitted to learn to read and write. It was not until the 19th century that many Hispanic women had the opportunity to become literate in Spanish or English. Even women who immigrated from Europe left very few literary traces before the 1830s. The author examines all periods of American agricultural history. There is a list of references and an index in the back.

Douglass, Alexander HQ1410.J39

Knudsen, Barbara and Barbara A. Yates. The Economic Role of Women in Small Scale Agriculture in the Eastern Caribbean: St. Lucia. Women and Development Unit, Extra-Mural Development, University of West Indies, Barbados, Pinelands, St. Michael, Barbados: The Unit, 1981.

The purpose of this study is to ascertain the extent and nature of economic participation by women in small-scale agriculture in St. Lucia. Knudsen and Yates offer policies and strategies for the most efficient delivery of agricultural support services to improve the economic wellbeing of farm women and their families in St. Lucia. Research methods, questionnaires and a short list of reference are included.

Douglass HD6073.A292S125 1981

Marti, Donald B. Women of the Grange: Mutuality and Sisterhood in Rural America, 1866-1920. New York: Greenwood Press, 1991.

The Grange is a secret fraternal organization that first appeared in 1866, flourished during the 1873 depression, declined abruptly after 1875 , and slowly revived in the 1880 s. Most of the earlier members were mid-western, but the second Granger movement that began in the $1880 \mathrm{~s}$ was predominantly eastern. The organization fostered cooperative enterprises, called for economic reforms, and tried to improve farmers' social and intellectual lives by bringing neighbors together for what were intended to be enjoyable and stimulating meetings. The Grange was always meant to serve farmers in particular, but it has never been an 
organization of farmers exclusively. The author observes women's participation in Grange activities, the role they played on the committees and the extent in which men and women could participate together in certain ceremonies. Each chapter has a long list of references. Douglass HD1485.N39M37 1991

Rosenfeld, Rachel Ann. Farm Women: Work, Farm, and Family in the United States. Chapel Hill: The University of North Carolina Press, 1985.

The focus of this book is on women who operate their own farms or are wives of farm operators. It also looks at how the nature of their farm and their families shape their work on and off the farm, with and without pay. The book is based on data from the federal Census of Agriculture. The author also participated as a researcher in the U.S. Department of Agriculture, Farm Women's Survey in 1980. In this survey, telephone interviews were conducted with 2,509 female farm operators and 569 male farm operators to determine the extent of the farm women's work, decision making, and off farm employment.

The data show that farm women's work changed according to the characteristics of the farm, the women's age and education, and the number of children in the family. In the Appendix are the questionnaires used for the survey, and an extended list of references. Douglass, Alexander, Camden, Dana HD6073.A292U67 1985

Ross, Lois L. Harvest of Opportunity: New Horizons for Farm Women. Saskatoon, Saskatchewan: Western Producer Prairie Books, 1990.

This book focuses on the work farm women are doing today, why they are doing it, and the obstacles they face while discovering and asserting their identities. The book includes information on common concerns such as rural day care, financial independence for farm women, business know-how, or the isolation of farm life. In all of these endeavors, the rural women have found a sense of self-worth and increasing self-confidence. Douglass HD6073.F32U673 1990

Ruchwarger, Gary. Struggling for Survival: Workers, Women and Class on a Nicaraguan Farm. Boulder, CO: Westview Press, 1989.

The author is the founder of a research program devoted to in-depth case studies on Nicaraguan mass organization. In this book he examines the economic context of a tobacco and vegetable state farm including 
the class structure and the conflicts among workers, technicians and managers. He also assesses the extent to which the feminization of the rural labor force and the organization of women workers have affected gender relations. In the Appendix are notes on recent theories on class and gender, a selected bibliography and an index.

Alexander, Dana HD1493.N5R83 1989

Sachs, Carolyn E. The Invisible Farmers: Women in Agricultural Production. Totowa, NJ: Rowman \& Allanheld, 1983.

The primary purpose of this book is to explore the full range of women's involvement in agricultural production through historical research and interviews with contemporary women. Sachs explores the reasons why women's role in Nicaraguan agriculture is ignored or overlooked. The author offers practical suggestions for reforming the unequal sexual division of labor.

Douglass, Alexander, Kilmer, Dana S441.S25 1983

Simonsen, Thordis, Editor. You May Plow Here: The Narrative of Sara Brooks. New York: Simon \& Schuster, Inc., 1986.

This book is a first person account of the life of Sara Brooks, who grew up on an Alabama farm in the early 1900s. Brooks recalls in detail the work of cotton picking, harvesting corn, and butchering hogs on the farm. Although the family was self-sufficient and raised all their own food, Brooks also remembers the hard work and poverty.

Alexander, Dana E185.97.B82A3 1987

Whitehead, Vivian B. Women in American Farming: A List of References. Davis, CA: Agricultural History Center, University of California, Davis, CA, 1987.

This is a bibliography of over 1000 periodical articles, books and government publications on women in American agriculture. Whitehead gathered the references from works in the National Agricultural Library, Library of Congress and the Agricultural History Branch of the USDA. The book is arranged alphabetically by author with a brief annotation accompanying most citations.

Alexander Z7963.E7W45 1987 


\section{Africa}

Bay, Edna G. Editor. Women and Work in Africa. Boulder, CO: Westview Press, 1982.

This is a collection of papers from a symposium held in 1979 at the University of Illinois, at Urbana-Champaign. The purpose of the symposium was to promote the field of economic studies on women in Africa, and to provide a forum for exchange of ideas among scholars and professionals concerned about women.

The book is divided into four sections and covers topics on women's production outside the development process; economic change and ideological conflicts; differential effects of development policies, and women and work in Africa. The authors present 14 case studies with relevant references, and statistics.

Douglass, Alexander, Camden, Dana HD6207.W65 1982

Boserup, Ester. Women's Role in Economic Development. London: Allen \& Unwin, 1970 \& New York: St. Martin's Press, 1970.

This is one of the most cited studies of works on women in agricultural development. Ester Boserup, an economist, was the first to note the prevalence in Africa of female farming systems where all the tasks connected to food production are done by women. Boserup documented the ties between certain land use patterns and agricultural techniques, and the division of labor based upon gender. She regarded the African agricultural system as the prototype female farming system. Boserup analyzed the modernization of agriculture and the migration to the cities, and its effect in changing the sexual patterns of productive work. She also linked these patterns to population density, landholding systems and technology. She expressed concern that this transition would deprive women of their productive roles in the developing African societies and urged further study of these trends. There are over 60 statistical tables, references, and an author index.

Douglass, Alexander, Camden, Dana, Kilmer HD6223.B68 
Bukh, Jette. The Village Woman in Ghana. Uppsala: Scandinavian Institute of African Studies, 1979.

The author presents an analysis of data collected in a village, Tsito, in South East Ghana in 1973 and in 1976-77.

She analyzes the changes in the roles of both men and women in the public and domestic sphere of agricultural production. Bukh asserts that the development of the market economy and the introduction of cocoa cultivation brought a new social division of labor that allocated to women a major role within subsistence activities.

The men were drawn into the cash economy, first as cocoa producers and later on, when the condition for cocoa production changed, as migrant workers. The structural transformation of the society created more freedom for women, but the women are caught between their traditional responsibility for their children and lack of control over necessary economic resources, like land, labor and money. The number of divorces are increasing in the village, most often on the initiative of the women. Many statistical tables and a short bibliography are included.

Alexander HQ1816.Z8T753 1979

Creevey, Lucy E., Editor. Women Farmers in Africa: Rural Development in Mali and the Sahel. Syracuse, NY: Syracuse University Press, 1986.

The editor of this book is director of the program on "Appropriate Technology and Energy Management for Development", and Professor of City and Regional Planning at the University of Pennsylvania. The book contains papers which were presented at the Bamako Workshop on Training and Animation of Rural Women sponsored by the Food Corps Program International (CILCA), and co-sponsored by the Union of Mali Women. The first part of the book includes papers on women farmers in Mali and the Sahel; the second part contains case studies of ongoing projects on different development programs for rural women in the same area. The Appendix contains facts on the Sahel, an extensive bibliography and an index.

Alexander, Douglass HD6073.A292A358 1986

Dixon-Mueller, Ruth. Women's Work in Third World Agriculture Concepts and Indicators. Geneva: International Labour Office, 1985.

This study addresses a number of methodological issues relating to the conceptualization, collection and interpretation of indicators of the 
sexual division of labor in Third World agriculture. It reflects recent efforts to propose a new agenda for creating indicators and improving concepts and methods in the area of women's position in the family and household, education and training, economic production and legal rights and participation in decision-making in the household and the community. There are more than 30 tables and figures, a bibliography and an index.

Douglass HD6073.A292D442 1985

Gladwin, Christina H., Editor. Structural Adjustment and African Women Farmers. Center for African Studies, University of Florida, Gainesville: University of Florida Press, 1991.

This is a collection of 16 papers presenting viewpoints from noted African and Africanist social scientists concerning the debate about Structural Adjustment Programs (SAPs) in Africa. Papers cover structural adjustment and its impact on transformation, women farmers, adjustment policies, gender and the economy, and future prospects. Douglass HD6073.F32A3757 1991

Hay, Margaret Jean and Sharon Stichter, Editors. African Women South of the Sahara. London: Longman, Inc., 1984.

This textbook is divided in three parts covering African women in the economy, in the society and culture, and in politics and policy. The book is clearly intended as a textbook and our copy has been heavily used by the students (underlined and marked in the margin). The Appendix contains selected statistics on African women, a bibliography, backgrounds of contributors, and an index.

Douglass, Alexander, Kilmer HQ1788.A57 1984

ILO Tripartite African Regional Seminar on Rural Development and Women, Dakar, Senegal. Rural Development and Women in Africa. Geneva: International Labour Office, 1984.

This is the proceedings of a seminar organized by the World Employment Programme and the Association of African Women for Research and Development that took place in Dakar, Senegal in 1981.

The purpose of the seminar was to debate priority issues and recommend guidelines for policy-makers and planners for the improvement of the living and working conditions of rural women in Africa. The first part 
of the book includes an overview of the seminar and the second part contains 11 papers presented at the seminar. Each paper has a list of references.

Douglass HQ1240.5.A35I24 1984

Nelson, Nici, Editor. African Women in the Development Process. London: Frank Cass and Company Ltd., 1981.

This Special Issue of the Journal of Development Studies is devoted to women's role in the development process. Most of the articles relate to sub-Saharan Africa and deal with specific issues such as the impact of labor migration on the lives of the women, women's cooperatives, and strategies for mobilizing village women.

Douglass, Alexander HQ1787.A375 1981

De Wilde, John Charles, Editor. Experiences with Agricultural Development in Tropical Africa. International Bank for Reconstruction and Development, Baltimore: Johns Hopkins Press, 1967. 2 volumes.

A series of studies on the tropical regions of Africa covering a range of ecological conditions, different approaches to agricultural development, and cultural patterns. Volume 1 is a synthesis of the project and volume 2 presents case studies. The purpose of the project was to evaluate the programs and identify factors which accounted for success or failure. The factors examined included receptivity and incentives to change, labor, land intensification and farm economics, use of machinery, land tenure and land use priorities, agricultural extension, training and education, and credit, marketing and cooperatives.

Kilmer HD2117.D4 1967

Whipper, Audrey, Editor. The Roles of African Women: Past, Present and Future. Canadian Journal of African Studies, volume 6, number 2. Ottawa: Canadian Association of African Studies, 1972.

This issue of Canadian Journal of African Studies brings together articles about women in east, central and west African countries, which examine political roles and tactics, marital and family patterns, economic activities, education and the difficulties in changing of women's roles. 
African women have had very little participation in the development plans in their respective countries. Policy-making has generally consisted of coalitions of males from Western and African countries who made decisions regarding the roles of women. Three of the articles are in French.

Douglass HQ1787.R6

Women's Roles 8 Gender Differences in Development Series:

A series of case studies on Women's Roles and Gender Differences in Development which was designed to demonstrate that such analyses are not only essential, but also feasible within existing structures. They specifically make clear how women's roles and gender differences are ignored when development projects are implemented.

Palmer, Ingrid. The Impact of Male Out-Migration on Women in Farming: Cases for Planners. West Hartford, CT: Kumarian Press, 1985.

Douglass HD6073.A292D4472

Palmer, Ingrid. The Impact of Agrarian Reform on Women. West Hartford, CT: Kumarian Press, 1985.

Douglass HD6073.A292D447 1985

Staudt, Kathleen. Agricultural Policy Implementation: A Case Study from Western Kenya. West Hartford, CT: Kumarian Press, 1985.

Douglass, Camden, Dana HD26.5.Z8S73 1985

World Bank Discussion Papers:

These discussion papers present results of country analyses or research designed to encourage discussion, debate, and change in issues dealing with the status of women in developing countries.

Gittinger, J. Price. Household Food Security and the Role of Women. World Bank Discussion Paper \#96.

Douglass HD6073.A292A354 1990

Saito, Katrine A. and C. Jean Weidemann. Agricultural Extension for Women Farmers in Africa. World Bank Discussion Paper \#103.

Douglass S544.5.A4S25 1990 
Asia and Australia

Atal, Yogesh, Editor. Women in the Villages, Men in the Towns. Paris: Unesco, 1984.

National and international agencies have begun paying more attention to the problems of women, and have initiated several programs of action to facilitate their equal participation in the development process. This book presents a summary of the programs examining problems faced by women in Asia and reports of five case studies from three different regions in Asia. Each country study covers the following topics:

1. Country profile and description of the changing situations.

2. Characteristics of the rural migrant.

3. The women in the family left behind. (This is the prime focus of the studies which analyzed the variety of roles performed by women when men are not present).

4. Intensive case studies of the villages involved.

5. Community adjustment.

6. Case studies on family structure and communal lives of women.

The countries covered are Bangladesh, India, Philippines, Korea, and Thailand.

Douglass HQ1726. W67 1984

Croll, Elizabeth. Women and Rural Development in China: Production and Reproduction. Geneva: International Labour Office, 1985.

This study is part of the World Employment Programme, which comprises research, workshops and seminars, advisory services and field projects. The objective of the program is to find ways to improve the incomes and employment of working women in rural areas of China.

The study is presented into two parts. The first part outlines the main characteristics of the development policies and the reorganization of rural sectors in China from 1949 to 1978 . It analyzes the effects these policies had on women's productive and reproductive activities and assesses the extent to which both traditional and new ideological economic and organizational constraints continued to inhibit the position of women working in the rural sectors.

The second part of the study looks at the more recent political and socioeconomic rural policies and programs implemented in rural areas of 
China and examines the implications for the dual roles of peasant women in production and reproduction.

Douglass HD6200.C94 1985

James, Kerry. Women in Rural Australia. St. Lucia, Queensland: University of Queensland Press, 1989.

Women have always played a major role in rural work in Australia and currently one third of Australian farmers are women. The studies included in this book describe the problems faced by rural women in Australia and changes that are occurring. The chapters cover decisionmaking, community involvement, local government and women's participation, exploitation of women, immigrant women, and aboriginal women.

Douglass HQ1822.W66 1989

Kada, Ryohei. Part-time Family Farming: Off-Farm Employment and Farm Adjustments in The United States and Japan.Tokyo: Center for Academic Publications Japan, 1980.

This is a comparative study of part-time family farming in the United States and Japan. The author conducted interviews with farm families in both countries to identify meaningful similarities and differences. The study also looks at part-time farming, which is becoming of greater importance as national economic development progresses. Kada examines the lives of farm families and the influences of farm operation, farm labor, life cycle of the families, aspirations and goals and off farm employment opportunities.

Each chapter presents relevant statistics and the book includes questionnaires used in the interviews, a short bibliography and an index. Dana HD1476.J35K3

Kurian, Rachel. Women Workers in the Sri Lankan Plantation Sector: A Historical and Contemporary Analysis. Geneva: International Labor Office, 1982.

This study examines the nature and evolution of the plantation system in Sri Lanka. The author analyzes the various activities undertaken by the female workers and the economic implications for the plantation sector and the country. The study includes a historical background of the Sri Lankan plantations; and a discussion of the sociological structure of plantation labor and its implications for women. 
Kurian examines the production and reproduction activities of women, income and expenditure, and welfare facilities. A bibliography is included at the end of the book.

Douglass HD6073.A292S684 1982

Mies, Maria. Indian Women in Subsistence and AgriculturalLabour. Geneva: International Labour Office, 1986.

This study was undertaken under the auspices of the World Employment Programme and the author presents a detailed analysis of working women in three villages in the state of Andhra Pradesh in India. The introduction gives a socioeconomic and historical background of the region. The author then examines the pattern of women's work and the level and source of their incomes and expenditures. She describes the roles of women as agricultural laborers, relationships with men and the impact of class, caste and gender on their lives.

Douglass HD6073.A292I46 1986

Nelson, Nici. Why Has Development Neglected Rural Women? A Review of the South Asian Literature. Oxford: Pergamon Press, 1979.

This book is part of the Women in Development Series. It deals with global economic development strategies and female emancipation. The author presents a review of literature and an overview of studies on the role of women in rural development in four countries in South Asia: Bangladesh, India, Pakistan, and Sri Lanka. It includes an extensive bibliography.

Alexander Z7964.S65N44 1979

Europe

Bridger, Susan. Women in the Soviet Countryside: Women's Role in Rural Development in the Soviet Union. Cambridge: Cambridge University Press, 1987.

This interesting book gives a history of rural women in the development of the Soviet Union. The old peasant family vanished, and in the rural family of 1987 , women tended to be better educated than their husbands, and often took the lead in decision making. The process of modernization through which these changes have been brought about 
is one over which rural women themselves had little control. Development planning remained in the hands of the Communist Party, in which rural women were always poorly represented.

The book is divided in three parts with the first part discussing women in the rural work force, the effect of the rural population's migration to the cities, women as machine operators and dairy farmers, and women in management. The second part looks at women in the rural family, emergence of smaller families, division of labor, parental influence in marriage and inequality within the marriage. In the final part of the book, the author includes information on women's roles in rural culture, education of rural women, women's religious beliefs and female participation in political activities. Each chapter has appropriate statistical tables and there is a bibliography and an index.

Douglass HQ1240.5.S65B75 1987

Farnsworth, Beatrice and Lynne Viola, Editors. Russian Peasant Women. Oxford: Oxford University Press, 1992.

The essays in this volume encourage readers to look at Russian history in new and different ways, and to question the assumptions that the Revolution was a unique milestone in women's history. The first essays treat peasant women before the Revolution describing their lives and family roles. Later chapters cover events after the Revolution and their place in Soviet agriculture. The paper on women in Soviet agriculture shows the extent to which agriculture became dependent on female labor following migration of the young and the men from the rural to the urban sectors throughout the Soviet Union. Women remained in the countryside and took over the hard labor in agriculture; very few held managerial positions or were employed in skilled and mechanized work in the collective-farm system. The essay demonstrates that stateinitiated modernization did not alter the position of women in agriculture. Each essay includes statistical tables and references.

Douglass HQ1662R875 1992

Zappi, Elda Gentili. If Eight Hours Seem too Fere: Mobilization of Women Workers in the Italian Rice Fields. Albany, NY: State University of New York Press, 1991.

This book is the first to present an accurate picture of the thousands of women who weeded the rice fields in Northern Italy during the early part of the 19th century. It includes a wide range of issues such as the 
history of the female labor force, their daily lives, and the efforts of the Socialist Party to lure women laborers away from the Catholic Church. The last chapter in the book covers the history of Italian feminism and the campaign for women suffrage. Labor actions of the women rice weeders were among the most radical of all workers in Italy prior to World War I. We find a lengthy bibliography and an index in the back. Douglass HD6073.R482I89 1991 